Plant Cell Reports (1997) 16:304-309

\title{
Pisatin metabolism in pea (Pisum sativum L.) cell suspension cultures
}

\author{
Wlodzimierz Borejsza-Wysocki, Ewa Borejsza-Wysocka, and Geza Hrazdina \\ Cornell University, Institute of Food Science, Geneva, NY 14456-0462, USA \\ Received 6 March 1996/Revised version received 30 May 1996 - Communicated by V. De Luca
}

\begin{abstract}
Cell suspension cultures were established from germinating pea (Pisum sativum L.) seeds. This cell culture, which accumulated pisatin, consisted mostly of single cells containing a few cell aggregates. The cells responded to treatment with a yeast glucan preparation with transient accumulation of pisatin in both cells and culture media. Addition of pisatin to cell cultures resulted in increased synthesis of pisatin. Phenylalanine ammonia-lyase, chalcone synthase and isoflavone reductase activities were present in untreated cells. Upon treatment with an elicitor preparation the activities of the first two enzymes showed a rapid, transient increase up to 20 hours after treatment. Isoflavone reductase showed a major and minor peak at 16 and $36 \mathrm{~h}$, respectively, after elicitor treatment. The time course of the enzyme activity and pisatin accumulation is consistent with an elicitormediated response.
\end{abstract}

ABBREVIATIONS: CHS, chalcone synthase; 2,4-D, 2,4dichlorophenoxyacetic acid; IBA, indole-3-butyric acid; IFR, isoflavone reductase; $2 \mathrm{iP}$, 6-(dimethylallylamino)-purine; $\mathrm{MS}$, Murashige \& Skoog basal salt medium; PAL, phenylalanine ammonia-lyase; PMSF, phenylmethylsulfonyl fluoride; POPOP, 1,4-bis-2-(4-methyl-5-phenyloxazolyl)-benzene; PPO, 2,5-diphenyloxazole.

KEY WORDS: cell culture, chalcone synthase, defense response, elicitor, isoflavone reductase, phenylalanine ammonia-lyase, pisatin, Pisum sativum

\section{INTRODUCTION}

Investigations involving plant-pathogen interaction have often used pea as a model system. These led to the isolation and structure determination of pisatin, the pea phytoalexin (Cruickshank and Perrin, 1960; Perrin and Bottomley, 1962; Perrin and Perrin, 1962). Early (Hadwiger, 1966; Banks and Dewick, 1982,1983; VanEtten et al., 1983) as well as more recent investigations (Preisig et al., 1990; Sun et al., 1992; Paiva et al., 1994) relied on $\mathrm{CuCl}_{2}$ treated pea seedlings as a model system to induce the formation of pisatin. The use of pea seedlings however, posed a number of problems that impeded biochemical and molecular investigations on the synthesis and accumulation of pisatin. Some of these impeding factors were that the seedlings did not present a homogenous material; germination of the seeds was not synchronous, and treatment of the seedlings with $\mathrm{CuCl}_{2}$ had direct effects on the epidermal layer, which comprises only a small fraction of all cells in the seedling. Hence, the rate of mRNA transcription and synthesis of pathway enzymes was generally low, making biochemical and molecular investigations more difficult and cumbersome. In addition to these above problems, the seedlings also produced a viscous polysaccharide material that interfered with enzyme purification and with RNA analysis. Clearly, a more homogeneous and manageable system was needed to facilitate further studies on pisatin biosynthesis and genetic control.

Since elicitor treated cell suspension cultures provided a usable model system to study phytoalexin biosynthesis in other plants (Dixon et al., 1983; Kombrink and Hahlbrock, 1986; Lange et al., 1994), it was expected that pea tissue cultures may also prove to be a useful model system for the study of pisatin biosynthesis (Fig. 1). This report describes methods to establish pea cell suspension cultures, and provides evidence that pisatin biosynthesis is induced in the cells upon treatment with an elicitor preparation.

\section{MATERIALS AND METHODS}

\section{Establishment of callus and cell suspension cultures}

Callus cultures were initiated from germinated seeds of the breeding line B 786-287-(1) from Dr. G.A. Marx's collection (Robbs et al., 1991). The pea seeds were sterilized with $75 \%(\mathrm{v} / \mathrm{v})$ ethanol and $5 \%$ (v/v) Clorox. Callus induction was initiated concurrently (in dark at $25^{\circ} \mathrm{C}$ ) on MS (Murashige \& Skoog 1962), A (Anderson 1980), and B5 (Gamborg et al., 1968), media supplemented with $2 \mathrm{mg} \mathrm{l}^{-1} 2,4-\mathrm{D}$, $1 \mathrm{mg} \mathrm{l}^{-1} 2 \mathrm{iP}, 1 \mathrm{mg} \mathrm{l}^{-1}$ IBA, $0.5 \mathrm{mg} \mathrm{l}^{-1}$ nicotinic acid, $0.5 \mathrm{mg} \mathrm{l}^{-1}$ pyridoxine hydrochloride, $0.1 \mathrm{mg}^{-1}$ thiamin hydrochloride, 100 $\mathrm{mg} \mathrm{l}^{-1}$ myo-inositol, $30 \mathrm{~g} \mathrm{l}^{-1}$ sucrose, and solidified with $7 \mathrm{~g} \mathrm{l}^{-1}$ Difco agar. After approximately 3 weeks, calli were separated from explants, transferred to baby food jars containing Gamborg's basal salt mixture supplemented as above and subcultured at 3-week 


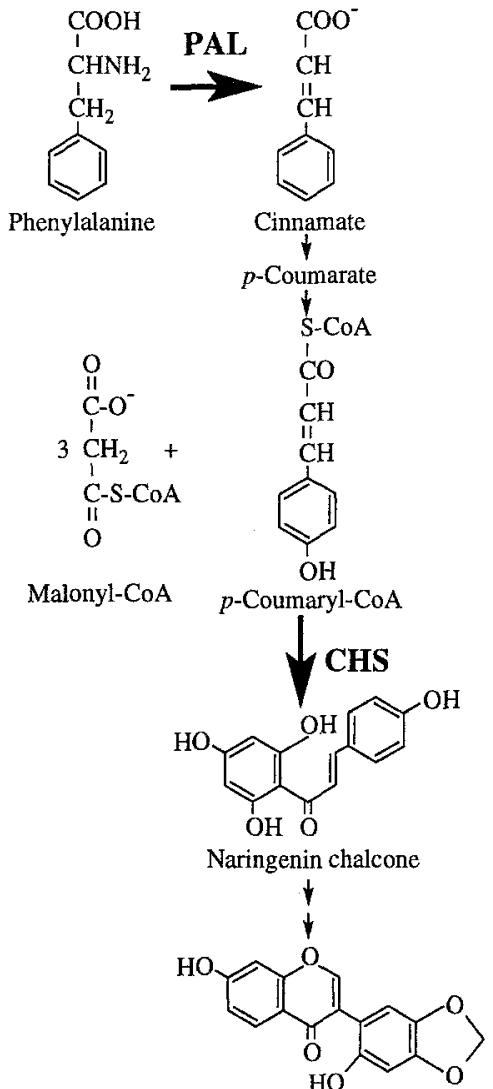

7,2'-Dihydroxy-4',5-methylenedioxyisoflavone (DMI)

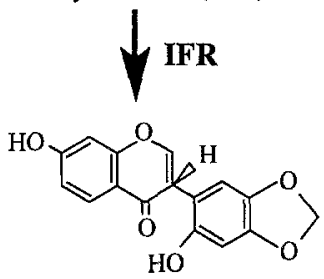

(-) Sophorol

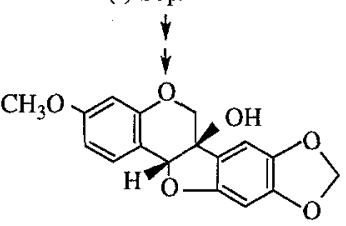

(+) Pisatin (pea phytoalexin)

Figure 1. Simplified schematic of $(+)$ pisatin biosynthesis in pea.

intervals. Cultures were maintained in the dark at $25^{\circ} \mathrm{C}$

Cell suspension cultures were initiated by adding $40 \mathrm{~g}$ of callus in a 41 Erlenmeyer flask containing 0.51 liquid B-5 medium, supplemented as described for callus cultures. The cultures were grown in darkness on a shaking incubator (Model G25 New Brunswick Scientific Co. Inc. $(150 \mathrm{rpm})$ at $25^{\circ} \mathrm{C}$. Cells were harvested at 10-14 day intervals on a 60 mesh screen and transferred into fresh medium. After 35 passages the growth of the cell suspension culture was quantified (from 3 replications) by determining fresh weight (Stepan-Sarkissian and Grey 1990) and protein (Bradford, 1976). Cells were harvested at daily intervals, weighed and frozen in liquid nitrogen for further analysis. Culture medium was used for determining sucrose concentration, $\mathrm{pH}$ and conductivity.

\section{Elicitor preparation and application}

Elicitor was prepared from $1 \mathrm{~kg}$ bakers yeast according to Schumacher et al. (1987). The solid isolated in the second step of ethanol precipitation was freeze dried, assayed for glucose equivalents as described by Dubois et al. (1956) and stored at $-20^{\circ} \mathrm{C}$ for later use. A sample of $5 \mathrm{mg}$ dry elicitor ( $1 \mathrm{mg}$ glucose equivalent per $100 \mathrm{ml}$ medium) was dissolved in $1 \mathrm{ml}$ distilled water, filtersterilized and added aseptically to fresh culture medium. Fresh culture medium without elicitor was used as control. Five day old pea cells were harvested, and $3 \mathrm{~g}$ cells were transferred as inoculum into $150 \mathrm{ml}$ conical flasks containing $30 \mathrm{ml}$ of fresh liquid culture medium. Cells were harvested at specific intervals, frozen in liquid nitrogen, and stored at $-90^{\circ} \mathrm{C}$ for enzyme assays or pisatin determination. Likewise, the culture medium from cell suspensions was frozen and used for pisatin determination.

\section{Determination of pisatin}

Pisatin was determined both in cells and culture media. Cells (3 g) were homogenized in methanol $(6 \mathrm{ml})$, the homogenate was centrifuged at $11,500 \mathrm{~g}$ for $5 \mathrm{~min}$, and the supernatant was decanted. Methanol was evaporated under vacuum at $40^{\circ} \mathrm{C}$ and ethyl acetate $(1: 2 \mathrm{v} / \mathrm{v})$ was added. Samples were extracted for $15 \mathrm{~min}$, the ethylacetate phase was separated by centrifugation $(11,500 \mathrm{~g}$ for 5 $\mathrm{min}$ ) and evaporated to dryness. The residue was dissolved in methanol. Pisatin was extracted directly from the filtrate with ethyl acetate $(1: 2 \mathrm{v} / \mathrm{v})$. The extract was processed as above. To determine the effect of pisatin on the cell cultures, we have isolated the compound from elicited pea cell suspensions using HPLC. The isolated pisatin was dissolved in ethanol (ca. $500 \mu \mathrm{l})$ and added to fresh culture medium $(30 \mathrm{ml})$ at $0.5 \mathrm{mM}$ concentration. The culture medium was inoculated with $3 \mathrm{~g}$ of 5 day old cells and samples were harvested for analysis at $24 \mathrm{~h}$ intervals. Pisatin was measured using HPLC on an Alltech C 18 column with $34 \%$ acetonitrile as solvent. Pisatin concentration was determined from a calibration curve with standard pisatin.

\section{Enzyme assays}

All manipulations were carried out at $4^{\circ} \mathrm{C}$. Cells $(3 \mathrm{~g})$ were homogenized in a chilled mortar with $6 \mathrm{ml}$ of $0.2 \mathrm{M}$ potassium phosphate buffer $\mathrm{pH} 8.0$, containing $6 \mathrm{mM}$ mercaptoethanol and 1 $\mathrm{mM}$ PMSF. Homogenates were centrifuged at $11,500 \mathrm{~g}$ for $5 \mathrm{~min}$, and the supernatant was used directly for assaying PAL, CHS, and IFR. Activity of PAL was determined by a radiotracer method according to Hrazdina and Parsons (1982). CHS assays were carried out as described earlier (Hrazdina et al. 1986). The IFR assay was based on the method of Tiemann et al. (1987) as described by Sun et al. (1991). Sophorol, the reaction product of the isoflavone reductase was quantitated by HPLC.

\section{RESULTS AND DISCUSSION}

\section{Cell suspension cultures}

We have used the pea breeding line B786-287(1) for callus initiation. Our previous experiments using Green Alaska pea cultivar resulted in the formation of hard calli that were not suitable for cell suspension culture. Similar observations were reported by other investigators (Jacobsen et al. 1980, Stirn and Jacobsen 1987 and Hashimoto et al. 1992). Callus formation with the breeding line B 786-287(1) was observed on all three media used (e.g. A, B-5 and MS). The B-5 medium and growing embryonic plant parts were found to 

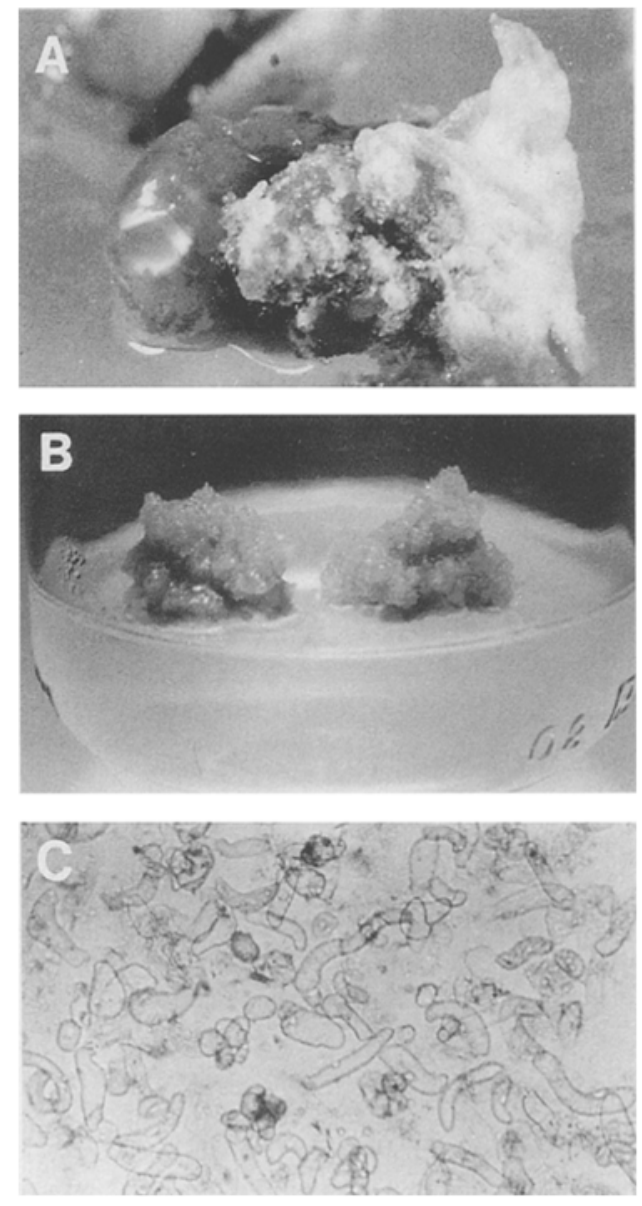

Figure 2. Establishment of pea cell suspension cultures. (A)-callus formation during seed germination (14-th day), (B)-21-day old callus culture, (C)-cell suspension culture (10 day old).

be the most suitable for callus establishment (Fig. 2A). The calli so produced were different in hardness (soft to hard) and also in color (light yellow to dark). We have not noticed a direct relationship between callus firmness and color. Calli formed from epicotyl sections were usually lighter and softer than those formed from hypocotyl sections. Hemispherical masses of calli excised from germinated seeds (approximately after 3 weeks) and transferred to fresh medium showed a reduced growth. Calli also turned brown frequently during the first transfers, but growth of yellow colored callus was observed on the top of the brown, older tissue after approximately two weeks of culture. Only light, soft calli were separated and propagated (Fig. 2B). Calli were subcultured for approximately one year before cell suspension cultures were started. During this subculturing light colored, friable calli were preferentially selected. In the liquid media the soft calli disintegrated to single spherical or elongated cells and small cell aggregates (Fig. 2C). During the vigorous shaking $(150 \mathrm{rpm})$ both single cells and small cell aggregates proliferated. To eliminate the proliferation of cell aggregates the cultures were gently ground in a mortar and filtered
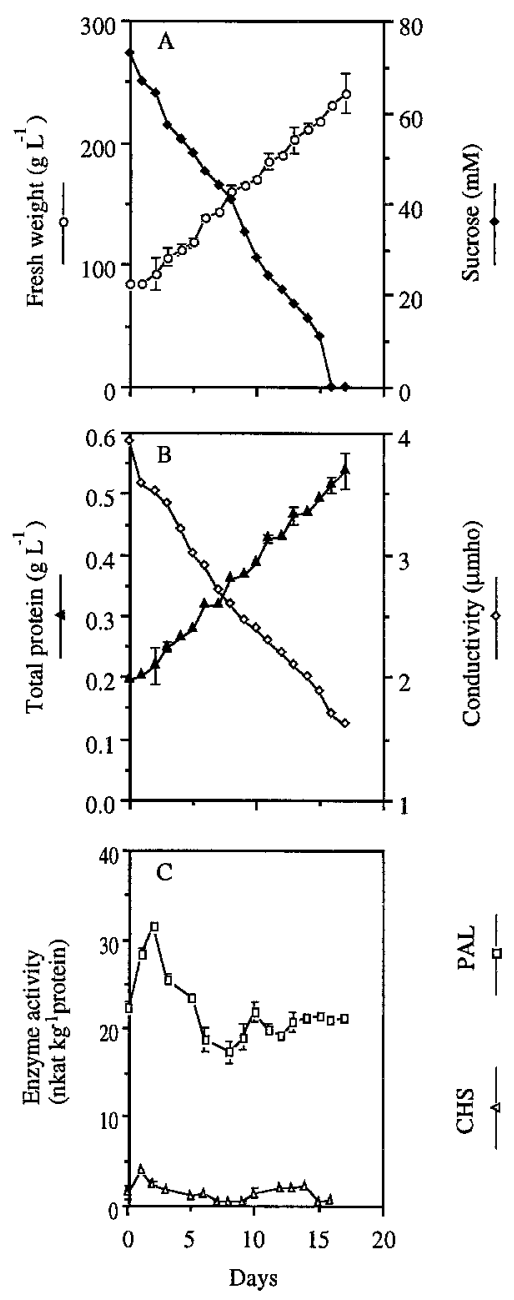

Figure 3. Changes in fresh weight and sucrose concentration (A), total protein and conductivity (B), and PAL and CHS activities (C) of pea cell suspension cultures as function of time. Bars indicate $\pm \mathrm{SE}$.

through a 60 mesh stainless steel sieve after every 5-6 transfers. This resulted in the production of uniform cell cultures, that consisted mainly of single cells. This manipulation had to be repeated after every five transfers to prevent cell aggregation. Cell cultures showed a linear growth rate for eighteen days after transfer to fresh medium. During this time period cell mass increased three-fold (Fig. 3A) as did protein concentration (Fig. 3B). Sucrose concentration and conductivity of the media showed an inverse relationship to cell mass. Sucrose decreased to near zero level, while conductivity decreased from $3.7 \mu$ mho to approximately $1.5 \mu \mathrm{mho}$. One of the characteristics of established cell suspension cultures is the induction of PAL activity in the cells upon their transfer to fresh culture media (Hahlbrock et al., 1971). Pea cell cultures showed this PAL induction (Fig. 3C), behaving similarly to those from parsley (Hahlbrock et al., 1971) and beans (Lawton et al., 1983). The activity of PAL was already elevated in the cells at the time of transfer, and it increased rapidly up to two days. The increase in activity was transient. The activity of the 

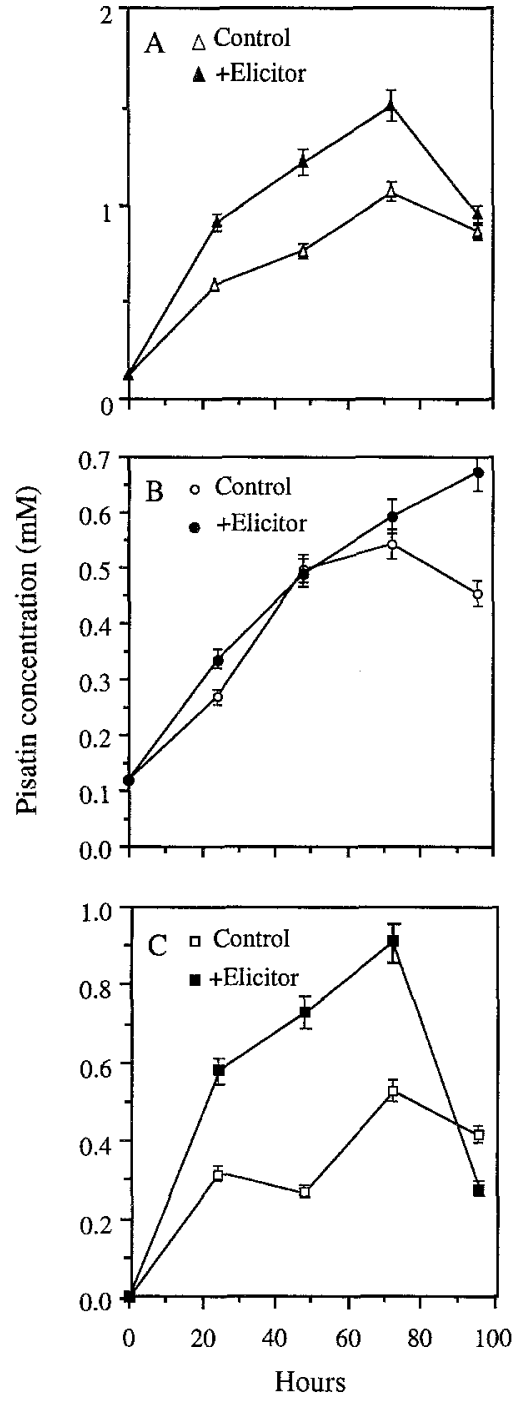

Figure 4. Pisatin accumulation in pea cell suspension cultures treated with elicitor (A-cell suspension, B-cells, C-culture medium). Bars indicate $\pm \mathrm{SE}$.

enzyme after four days decreased to below that measured upon transfer of the cells to the medium. Such a fresh medium effect was observed with PAL only. The activity of CHS, the rate controlling enzyme of the specific flavonoid pathway (Grisebach and Hahlbrock, 1974) was not affected by transfer of the cells, remaining low during the time course of the experiment.

\section{Accumulation and metabolism of pisatin}

Untreated pea cells grown in B-5 medium showed the presence of approximately $0.1 \mathrm{mM}$ pisatin in the cell suspension. Pisatin content of the untreated cell suspension increased approximately ten fold of the original value in a 72 hour period, and showed a marked decline thereafter. A similar observation was made with pea callus (Bailey, 1970). When a pea cell suspension was exposed to the elicitor (one mg glucose equivalent per $100 \mathrm{ml}$ medium), the cell cultures responded with an increased production of pisatin (Fig. 4A) compared with untreated cells. Pisatin accumulated up to 72
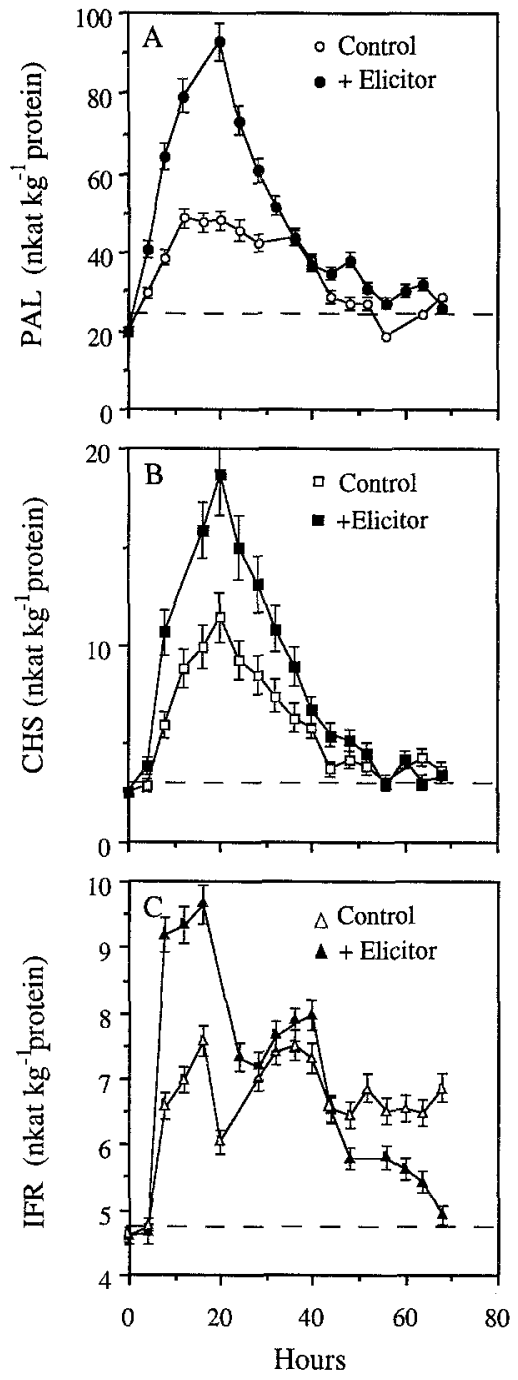

Figure 5. Induction of PAL (A), CHS (B) and IFR (C) activities in pea cell suspension cultures treated with elicitor. Dashed line represents enzyme activity in the cells without transfer to fresh medium or elicitor treatment. Bars indicate \pm SE.

hours after cell exposure to elicitor, after which it declined to levels found in untreated cells.

To investigate whether pisatin is accumulated within the cells or it is secreted into the medium, we have measured the accumulation of the compound in both filtered cells (Fig. 4B) and in the culture medium (Fig. 4C). Pisatin concentration in untreated cells was found to be approximately $0.5 \mathrm{mM}$ after $72 \mathrm{~h}$ propagation, and started to decline thereafter. Elicitor treated cells showed a continuous accumulation of pisatin up to 100 hours at which time the experiments were terminated (Fig. 4B).

Pisatin accumulated in the culture medium both in the presence and absence of the elicitor. Pisatin levels reached $0.4 \mathrm{mM}$ concentration in untreated media, while the compound accumulated to $0.9 \mathrm{mM}$ concentration in the presence of the elicitor (Fig. 4C). The highest pisatin accumulation in elicitor-treated media occurred 72 hours after treatment, after which it rapidly declined to approximately 

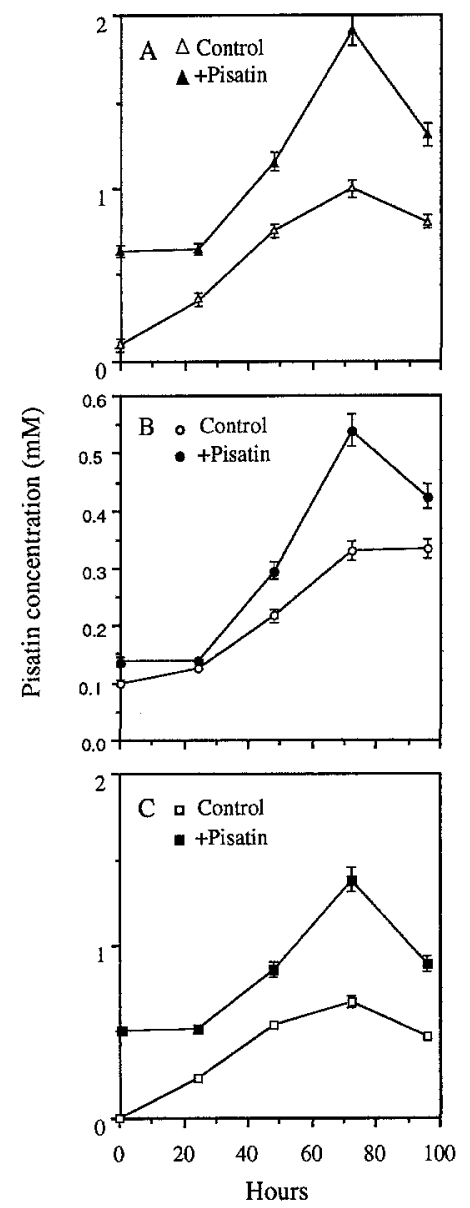

Figure 6. Pisatin accumulation in pisatin treated pea cell suspension cultures (A-cell suspension, B-cells, C-culture medium). Bars indicate $\pm \mathrm{SE}$.

$0.3 \mathrm{mM}$ at 100 hours. This rapid decline of pisatin concentration in the elicitor containing culture medium indicated either uptake, or metabolism of pisatin by the cells.

\section{Induction of the activity of key pisatin biosynthetic enzymes}

Figure 1 shows the simplified biosynthetic scheme of the $(+)$-pisatin pathway. The pathway is regulated by several enzymes and was investigated earlier by others (Banks and Dewick, 1982; 1983; Preisig et al., 1990; Sun et al., 1991, Sun 1992; Paiva et al., 1994). We have selected PAL, CHS and IFR, the key enzymes of the pisatin pathway (see Fig. 1), to examine their activities in cell-free extracts of elicitor treated and untreated pea cells (Fig. 5). In the absence of elicitor, enzyme activity was induced when cells were transferred to fresh medium. A similar response (i.e. induction of enzyme activities and phytoalexin formation) was observed earlier in other plant cell suspension cultures in the absence of fungal elicitors and was termed autoelicitation (Apostol et al., 1989). Elicitor treatment of pea cell suspension cultures resulted in increases in the extractable activity of all three enzymes (Fig.5), and this was correlated to increased pisatin accumulation (Fig.4). The activity of PAL approximately doubled upon addition of fresh medium to the cells (Fig. 5A). However, when cells were treated with culture media containing the elicitor, PAL activity increased nearly four-fold from its pre-treatment value. Highest PAL activity was observed 24 hours after elicitor treatment. Activity of PAL rapidly decreased thereafter and reached pre-treatment values approximately at $48 \mathrm{~h}$. The activity of CHS (Fig. 5B), the key enzyme of flavonoid biosynthesis, showed similar transient changes to those of PAL, but this enzyme increased approximately two-fold in the presence of the elicitor compared to unelicited control cells. Previous investigations in our laboratory showed that IFR is one of the key enzymes of pterocarpan phytoalexin biosynthesis (Paiva et al., 1994). The activity of IFR also increased transiently upon addition of fresh culture medium to the cells. This activity peaked twice, once after $18 \mathrm{~h}$ and again approximately $40 \mathrm{~h}$ after addition of the fresh medium (Fig. 5C). Treatment with the elicitor showed an approximately two-fold increase of the first activity peak (18 h), while the second peak ( $40 \mathrm{~h}$ ) showed no significant change from that found with the untreated cells. There was sufficient PAL and CHS activity present in the cells during the induction period of IFR to account for the synthesis of pisatin.

To investigate whether the changes in pisatin concentration were the result of uptake or metabolism, $0.5 \mathrm{mM}$ pisatin was added to the pea cultures and its concentration was measured in the cell suspensions (Fig. 6A), cells (Fig. 6B) and culture medium (Fig. 6C). The presence of pisatin in the media caused an increased accumulation of the compound in the cells and also an increased export to the culture media. The cell suspension culture without addition of external pisatin accumulated this compound to approximately $0.9 \mathrm{mM}$ concentration, a similar value found in the control of the elicitor treated cell suspension. The cell suspension containing $0.5 \mathrm{mM}$ external pisatin showed accumulation of this compound at approximately $2.0 \mathrm{mM}$ levels, a value significantly higher than the sum of internal and external pisatin (Fig. 6A). Maximal accumulation of pisatin was observed at $72 \mathrm{~h}$ after treatment, after which the concentration of the compound declined to levels approximating the sum of internal and external pisatin. Similar data were observed with the cells (Fig. 6B) and the culture media (Fig.6C). These data indicate that addition of pisatin to pea cell suspension cultures induces the synthesis of the same. Presence of larger amount of pisatin in pisatin treated cell suspensions may indicate both uptake and accumulation. Decreases in pisatin concentration in cells and media are indicative of pisatin metabolism, either by glycosylation of the compound (Shiraishi et al., 1975; Kobayashi et al., 1993) or by degradation (VanEtten et al., 1989). HPLC separation of aromatic metabolites produced by the cell suspension cultures showed no increase in any peak that could have been correlated to decreasing pisatin levels (data not shown). Therefore, it seems likely that the decrease in pisatin concentration is the result of degradation of the compound.

The above discussed results show that the pea cell suspension culture is a suitable model system for biochemical investigations of the pisatin pathway. Accumulation of pisatin 
in the culture medium is in agreemament with the presently held view that phytoalexins are secreted to the cell wall and in the cellular spaces to counter fungal invasion (Mansfield 1982). Although this has been generally assumed to be the case, to our knowledge no published evidence existed on this. The observation that addition of pisatin to pea cell cultures induces the synthesis of the same seems to be unusual. This suggests that pisatin is not only toxic to the fungus, but apparently it also causes a stress response in the cells that produce the compound.

ACKNOWLEDGMENT. The research support provided in part by the National Science Foundation grant DCB 89116265 and by the Cornell Biotechnology Program, which is sponsored by the New York State Science and Technology Foundation, a consortium of industries, the U.S. Army Research Office, and the National Science Foundation, is gratefully acknowledged.

\section{LITERATURE CITED}

Anderson WC (1980) Acta Hort 112: 13-20

Apostol I, Low PS, Heinstein P (1989) Plant Cell Rep 7: 692-695

Bailey JA (1970) J General Microbiol 61: 409-415

Banks SW, Dewick PM (1982) Phytochemistry 21: 2235-2242

Banks SW, Dewick PM (1983) Phytochemistry 22: 1591-1595

Bradford MM (1976) Anal Bioch 72: 248-254

Cruickshank IAM, Perrin DR (1960) Nature 187: 799-800

Dixon RA, Dey PM, Lamb CJ (1983) Adv Enzym 55: 1-136

Dubois M, Gilles KA, Hamilton JK, Rebers PA, Smith F (1956) Anal Chem 28: 350-356

Gamborg OL, Miller RA, Ojima K (1968) Exp Cell Res 50: $151-158$

Grisebach H, Hahlbrock K (1974) Recent Adv Phytochem 8: $21-52$

Hadwiger LA (1966) Phytochemistry 5: 523-527

Hahlbrock K, Ebel J, Ortmann R, Sutter A, Wellmann E, Grisebach H (1971) Biochim Biophys Acta 244:7-15

Hashimoto T, Yamada T, Tada A, Kawamata S, Tanaka Y, Sriprasertsak P, Ichinose Y, Kato H, Izutsu S, Shiraishi T, Oku H, Ohtsuki Y (1992) Plant Cell Report 11: 183-187

Hrazdina G, Lifson E, Weeden NF (1986) Arch Biochem

Biophys 247: 414-419

Hrazdina G, Parsons GF (1982) Plant Physiol 70: 506-51
Jacobsen HJ, Ingensiep HW, Herlt M, Kaul MLH (1980) In: Sala F, Parisi B, Cella R, Ciferri O (eds) Plan cell culures: Results and Perspctives, Elsevier/North-Holland Biomedical Press, Amsterdam, pp 319-324

Kobayashi A, Akiyama K, Kawazu K (1993) Phytochemistry 32: 77-78

Kombrink E, Hahlbrock K (1986) Plant Physiol 81: 216-221

Lawton MA, Dixon RA, Hahlbrock K, Lamb CJ (1983) Eur J Biochem 130: 131-139

Lange BM, Trost M, Heller W, Langebartels C, Sandermann H (1994) Planta 194: 143-148

Mansfield JW (1982) In: Biley JA, Mansfield JW(eds) Phytoalex ins, A Halsted Press Book/John Wiley and Sons, New YorkToronto, pp 253-288

Murashige T, Skoog F (1962) Physiol Plant 15: 473-497

Paiva NL, Sun Y, Dixon RA, VanEtten HD, Hrazdina G (1994) Arch Biochem Biophys 312: 501-510

Perrin DR, Bottomley W (1962) J Am Chem Soc 84: 1919-1922

Perrin DD, Perrin DR (1962) J Am Chem Soc 84: 1922-1925

Preisig CL, Bell JN, Sun Y, Hrazdina G, Matthews DE, VanEtten HD (1990) Plant Physiol 94: 1444-1448

Robbs SL,Hawes MC, Lin H-J, Pueppke SG, Smith LY (1991) Plant Physiol 95: 52-57

Schumacher HM, Gundlach H, Fiedler F, Zenk MN (1987) Plant Cell Reports 6: 410-413

Shiraishi T, Oku H, Isono M, Ouchi S (1975) Plant Cell Physiol 16: $939-942$

Stepan-Sarkissian G, Grey D (1990) In: Pollard JW, Walker JM (eds) Methods in Molecular Biology, Plant Cell and Tissue Culture, vol 6. The Humana Press, Clifton, New Jersey, pp 13-27

Stirn S, Jacobsen HJ (1987) Plant Cell Report 6: 50-54

Sun Y (1992) Biosynthesis of pisatin in pea (Pisum sativum L.) seedlings: enzymological and molecular characterization of the isoflavone reductase. $\mathrm{PhD}$ dissertation. Cornell University.

Sun Y, Wu Q, Van Etten HD, Hrazdina G (1991) Arch Biochem Biophys 284: 167-173

Tiemann K, Hinderer W, Barz W (1987) FEBS Lett 213: 324-328

VanEtten HD, Matthews DE, Matthews PS (1989) Annu Rev Phytopathol 27: 143-164

VanEtten HD, Matthews PS, Mercer EH (1983) Phytochemistry 22: $2291-2295$ 